\title{
Il disegno della città nelle tavole del De Nola. Analisi geometrico-dimensionale delle iconografie
}

Alessandra Avella

Abstract

II paper presenta l'analisi della città antica di Nola attraverso lo studio di due Tavole tra le quattro accluse al De Nola di Ambrogio Leone (15|4), anche nel confronto con la città contemporanea. Tali disegni sono un'importante testimonianza grafico-documentale delle tracce della città antica in età rinascimentale nonché delle conoscenze teorico-geometriche dell'autore discusse nel presente saggio. La ricerca, a partire dalle analisi grafiche della Tavola II intitolata Nola Vetus, ne declina gli aspetti geometrico-dimensionali, basandosi sulla scienza del Disegno, non solo per una rilettura critica di tutte le Tavole allegate al Trattato, ma anche per connettere la città antica alle tracce tuttora presenti nel territorio contemporaneo.

II presente saggio, unitamente ai contributi di Argenziano e Pisacane in tale volume e in continuità con lo studio già presentato al Convegno UID 2020, consolida il carattere poliedrico dell'autore quale disegnatore, topografo e tipografo, nonchè erudito umanista.

Parole chiave

documentazione, geometria, sistemi di misura, trattatistica, UNESCO.

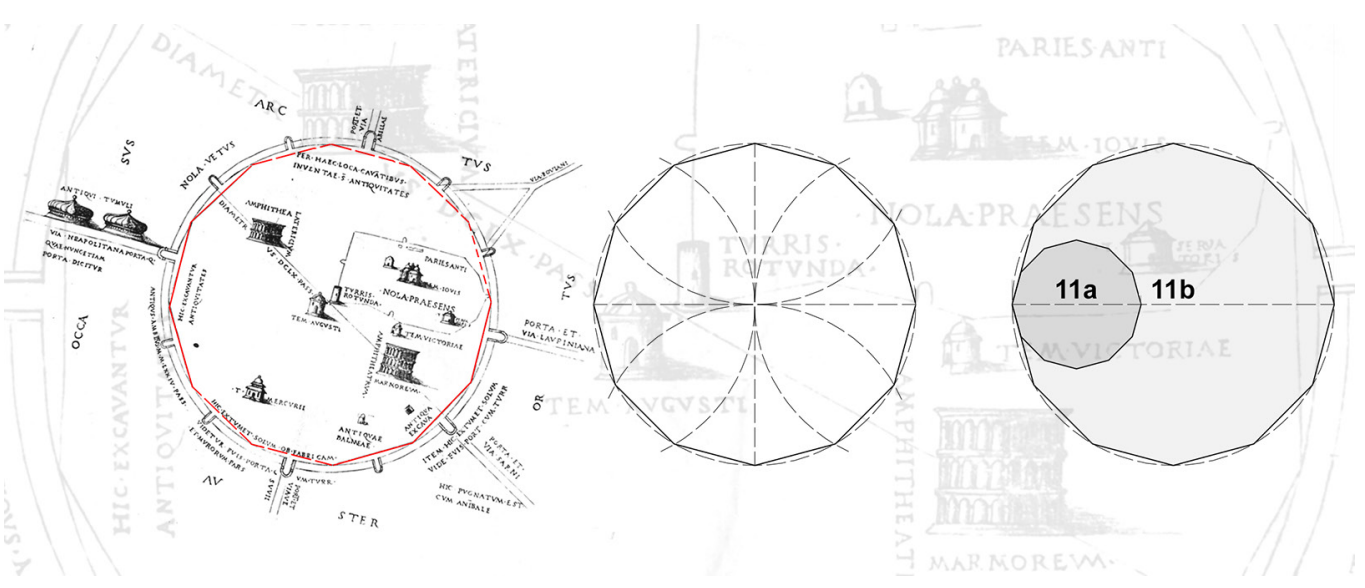




\section{Introduzione}

Questo paper prosegue [I] e integra [2] lo studio dei quattro disegni allegati alla prima edizione [3] del Trattato De Nola (15/4) di Ambrogio Leone [4] con I'analisi geometrica e grafica della Tavola II intitolata Nola Vetus. I quattro disegni analizzati sono un'importante testimonianza grafico-documentale della città rinascimentale di Nola descritta da Leone nei tre libri in cui articola l'Opera. L'autore descrive nel primo libro il territorio nolano con taglio cronologico e con un'ampia dissertazione sulla città classica - qui sono inserite la tavola Ager Nolanus (Tavola I) e la tavola Nola Vetus (Tavola II); nel secondo libro descrive la città a lui coeva e la sua struttura con approfondimenti sugli elementi difensivi, sulle emergenze architettoniche nobiliari, religiose e civili - qui sono inserite la tavola Figura praesentis urbis Nolae (Tavola III) e la tavola Nola Presens (Tavola IV); nel terzo libro, infine, narra gli usi e i costumi dei suoi concittadini dedicando ampio spazio alla tradizione della Festa dei Gigli [5], dal cui studio traggono spunto le analisi tuttora in corso sull'apparato illustrativo del De Nola. Tali analisi, infatti, sono parte di una più ampia ricerca sviluppata nell'ambito del Progetto finanziato dalla Regione Campania finalizzato allo studio per la salvaguardia e valorizzazione degli elementi culturali dell'autenticità dei Gigli di Nola, della sua festa e della sua comunità, iscritti nella lista del Patrimonio Immateriale UNESCO [6].

In analogia all'approccio metodologico proprio della disciplina del Disegno [7] già adottato per l'analisi delle Tavole I, III e IV, le analisi della Tavola II sono di carattere geometrico-dimensionale, relative ai metodi della rappresentazione, alle caratteristiche tipografiche e alle caratteristiche geografiche comparate alla cartografia contemporanea. In particolare, nel presente studio sono descritte ed illustrate le analisi di carattere geometrico-dimensionale della Tavola Nola Vetus a partire dal confronto con la Tavola Figura praesentis urbis Nolae, così come discusso nel paragrafo che segue.

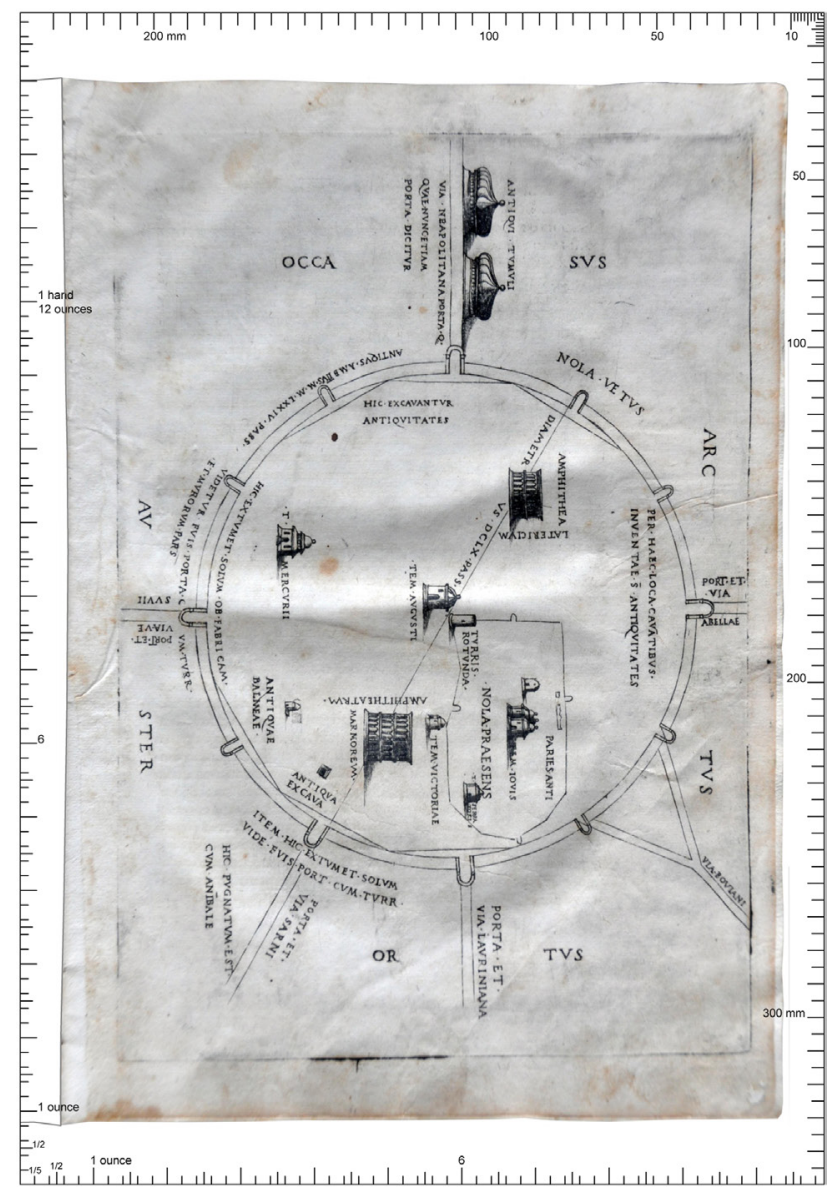




\section{Impianto geometrico e mensorio delle Tavole Nola Vetus e Figura praesentis urbis Nolae}

Lo studio della tavola Nola Vetus (Tavola II) [8], che illustra la città antica di Nola, e del relativo testo descrittivo nei Capitoli VII edVIII del primo libro, è condotta a partire dai risultati già raggiunti a seguito dell'analisi geometrica ed algebrica della tavola Figura praesentis urbis Nolae (Tavola III), I'unica delle quattro Tavole nella quale l'autore offre una accurata descrizione dell'immagine anche con precisi riferimenti sia al perimetro che all'estensione della città di Nola, tanto in età romana quanto in età rinascimentale.

Nelle figure I e 2 le immagini della tavola Nola Vetus e della tavola Figura praesentis urbis Nolae sono state orto-rettificate secondo la procedura utilizzata per le altre due Tavole [9] del De Nola e sono riportate nel presente contributo secondo la disposizione nelle pagine del Trattato (il margine di rilegatura a sinistra è evidenziato con un segmento marcato). La superficie interna al margine dei fogli è piana e l'immagine è stata riprospettata secondo una direzione ortogonale; ciononostante le deformazioni in alcune aree del foglio non possono essere state corrette. La cornice delle figure I e 2 è scandita in palmi e once - le unità di misura tra loro proporzionali, in uso al tempo di Leone nel Regno di Napoli per lunghezze di oggetti maneggevoli - e in centimetri e millimetri [10].

Le valutazioni geometrico-dimensionali proposte da Leone a commento della Tavola III sono necessarie per il confronto che l'autore conduce tra la forma circolare della città antica e quella mistilinea della città rinascimentale, come egli stesso dichiara nel testo, indicando come finalità di tale operazione quella di determinare "il diametro sicuro e paragonabile con il diametro dell'antica città" [I I]. II Leone riconduce la forma irregolare della città Rinasci-

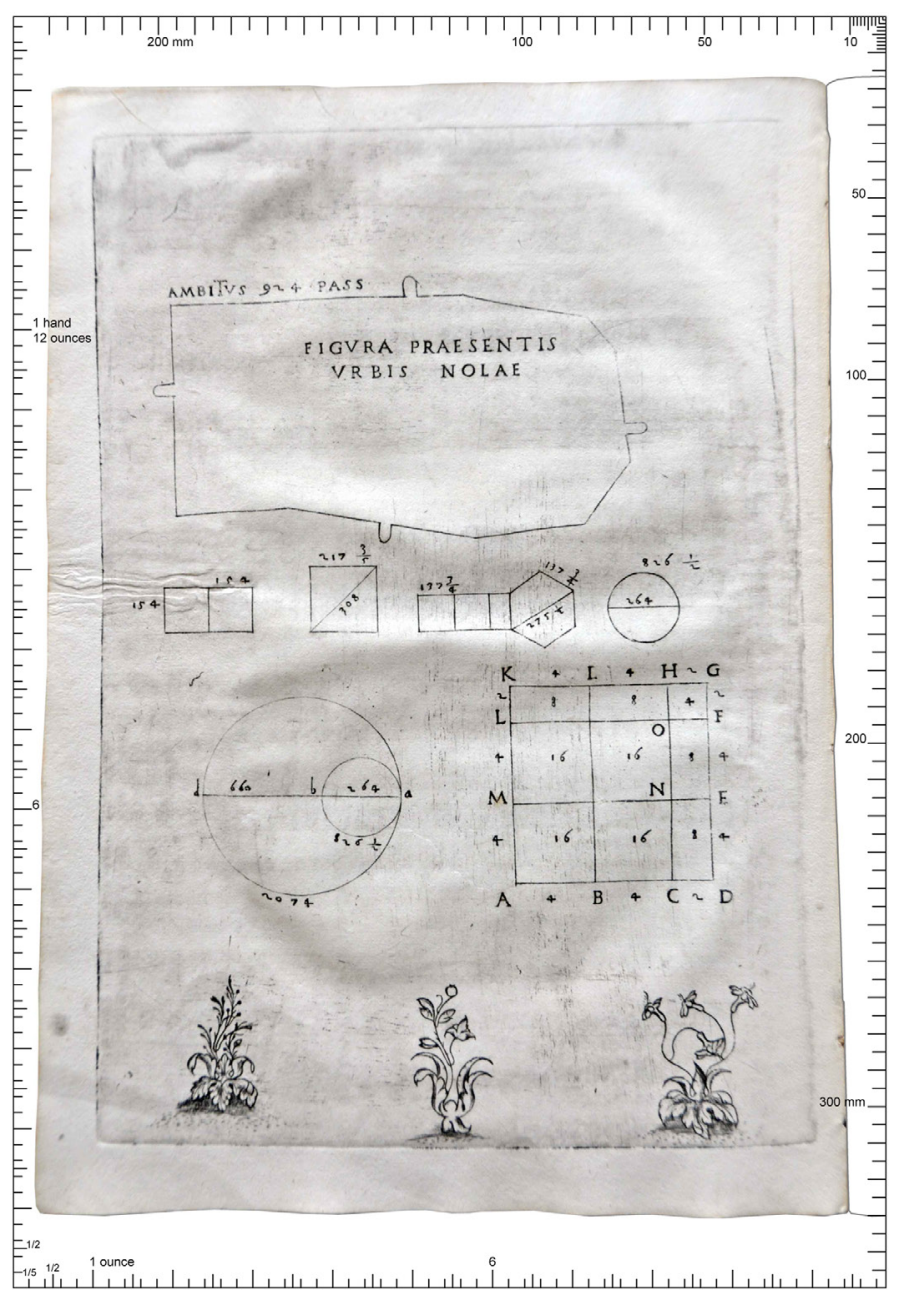


mentale a quella di una circonferenza attraverso trasformazioni geometriche del poligono di partenza sulla base di valutazioni critiche relative all'equivalenza tra figure. Quindi dal poligono irregolare di partenza della città Rinascimentale, che semplifica attraverso due quadrati affiancati di superficie totale equivalente, arriva alla circonferenza della città antica attraverso le figure geometriche del quadrato, dell'esagono e del poligono a dodici lati. II dodecagono scalato nelle dimensioni della città romana gli permette di collocare nei vertici le 12 porte della città. Tutti i grafici geometrici presenti nella Tavola III sono accompagnati da testi che riportano in alcuni casi l'indicazione dei perimetri delle figure, in altri le quotature dei singoli segmenti componenti i poligoni e le dimensioni delle circonferenze. Le misure sono espresse in passi e i sottomultipli dell'unità sono frazionari e non decimali, come in uso al tempo. I dati dimensionali ottenuti attraverso l'analisi grafica, le stime metriche ed il ri-disegno vettoriale delle figure geometriche della Tavola III hanno permesso di calcolare la scala di rappresentazione della Tavola e di tutti i disegni in essa rappresentati: la Figura paesentis urbis Nolae è disegnata in once, ciascuna oncia equivalente a 60 passi reali; le figure geometriche regolari sono in media 5 volte minori rispetto ad essa. Considerando i palmi come unità di misura, la scala di rappresentazione di ogni figura geometrica è di circa l:2000. Questa eterogeneità ha reso necessario scalare le Tavole ad una sola di esse per calcolare l'errore tra le dimensioni scritte da Leone e i disegni, valutando - all'esito di tale operazione - che l'errore calcolato può ritenersi trascurabile.

A partire da tali dati dimensionali a corredo dei disegni della Tavola III, ed in particolare di quelli relativi alla figura del dodecagono inscritto nella circonferenza di diametro pari a 660 passi, è stato eseguito il confronto con i dati dimensionali indicati nella Tavola II. Nello specifico, la figura 3 ripercorre non solo l'analisi geometrica dei disegni presenti nella Tavola Figura praesentis urbis Nolae, ma anche la descrizione che l'autore propone nel Capitolo illustrativo della stessa Tavola contenente anche considerazioni relative alle figure geometriche dell'esagono e del dodecagono. Sono proprio quelle riferite a quest'ultimo poligono regolare che hanno permesso il confronto con la Tavola Nola Vetus. All'interno del perimetro circolare della cinta muraria della città antica il Leone traccia sei dei dodici lati del dodecagono disponendo nei punti medi dei lati le porte della città.

Fig. 3. Tavola III: analisi geometrica e algebrica delle circonferenze e dei quadrati equivalenti alla forma urbana della città antica e di quella rinascimentale In basso sinistra in rosso il perimetristra in rosso il perlacittà antica ipotizzato città antica ipotizzato da Leone sovrapposto al Tavola II.
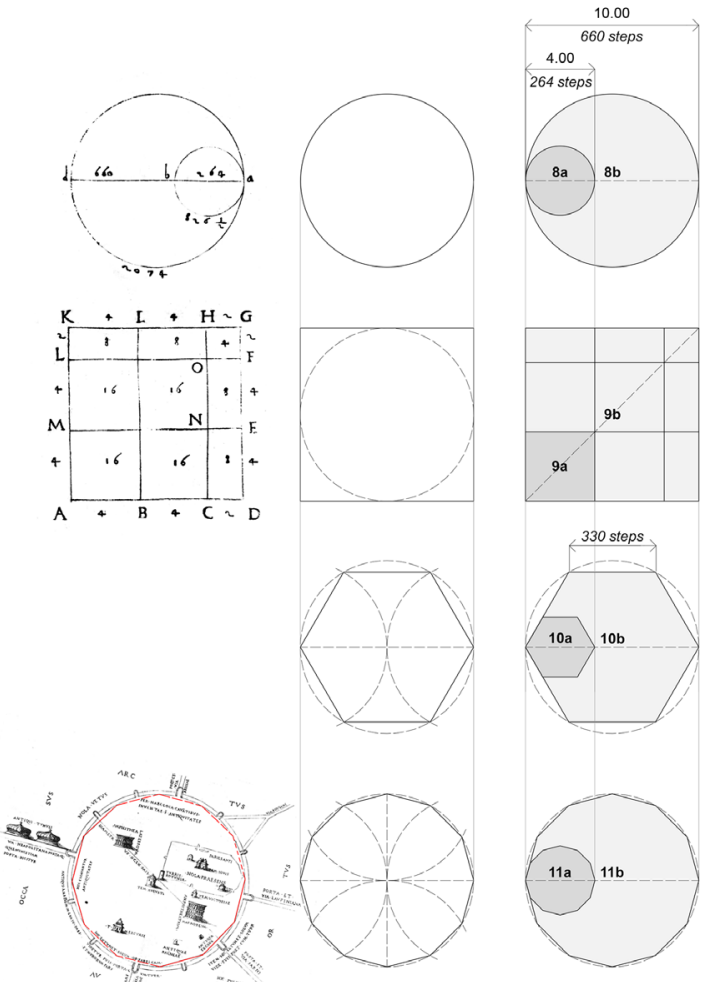
La Tavola II presenta elementi grafici utili al proporzionamento dell'immagine e delle sue parti, come già riscontrato nelle altre Tavole del Trattato. II rapporto tra i lati della cornice rettangolare di impressione tipografica (nella Tavola una cornice disegnata non è visibile) è di 12,5:8,5 once. La geometria caratteristica di questa tavola è evidentemente la circonferenza, il cui centro è stato individuato sul segmento indicato come diametrus, nell'intersezione con una retta passante per il margine verticale sinistro dell'icona indicata come Turris Rutunda. Tra le possibili circonferenze tracciate in software vettoriale - mediante il Teorema di Pascal - è stata scelta quella che ricalca la maggiore estensione della circonferenza minore disegnata nella tavola. $\grave{E}$ da evidenziare che quest'ultima si discosta da quella regolare nella parte superiore della tavola (Arctus) [12]; in questa area, il foglio risulta deformato forse per effetto dell'umidità e forse anche per l'usura causata dallo sfoglio delle pagine; il margine Arctus della tavola, infatti, è quello di sfoglio del libro come è evidente nella figura I nella quale il foglio è disposto secondo lo sfoglio del libro.

Data la circonferenza regolare tracciata nella figura 4 è da segnalare che ad una distanza trascurabile dal suo centro, ovvero dal segmento diametrus, si nota una piccola macchia che potrebbe essere la traccia residua della concentrazione dell'inchiostro nel punto (owero forellino) in cui il disegnatore pose l'ago del compasso sulla lastra di impressione tipografica. Questa traccia grafica potrebbe essere un altro indizio per confermare la validità della circonferenza regolare vettoriale, utilizzata come riferimento geometrico per tutte le analisi di questo paper e dei saggi di Argenziano e Pisacane pubblicati in questo volume, ai quali si rinvia per una lettura completa dello studio condotto sul tema.

Nella figura 4 un sistema di assi ortogonali ha origine nel centro della circonferenza con l'asse verticale tangente al margine sinistro dell'icona Turris Rutunda; l'asse verticale è perciò nella direzione Arctus-Auster. Rispetto al sistema di assi ortogonali si nota che il segmento indicato come diametrus è inclinato di $30^{\circ}$; ed ancora, si nota che gli assi verticali medi delle 12 porte urbiche sono disposti lungo la circonferenza con variazioni angolari che oscillano tra $28^{\circ}$ e $35^{\circ}$. Inoltre, le icone delle porte urbiche sono di due dimensioni: quelle aperte verso le direzioni cardinali principali e quella all'estremo inferiore del diametro disegnato sono ampie 0,25 once e sono alte 0,4 once, mentre tutte le altre sono più o meno in proporzione 0,2:0,3 once. Ciò potrebbe alludere ad una gerarchia nella funzione di queste porte. Anche
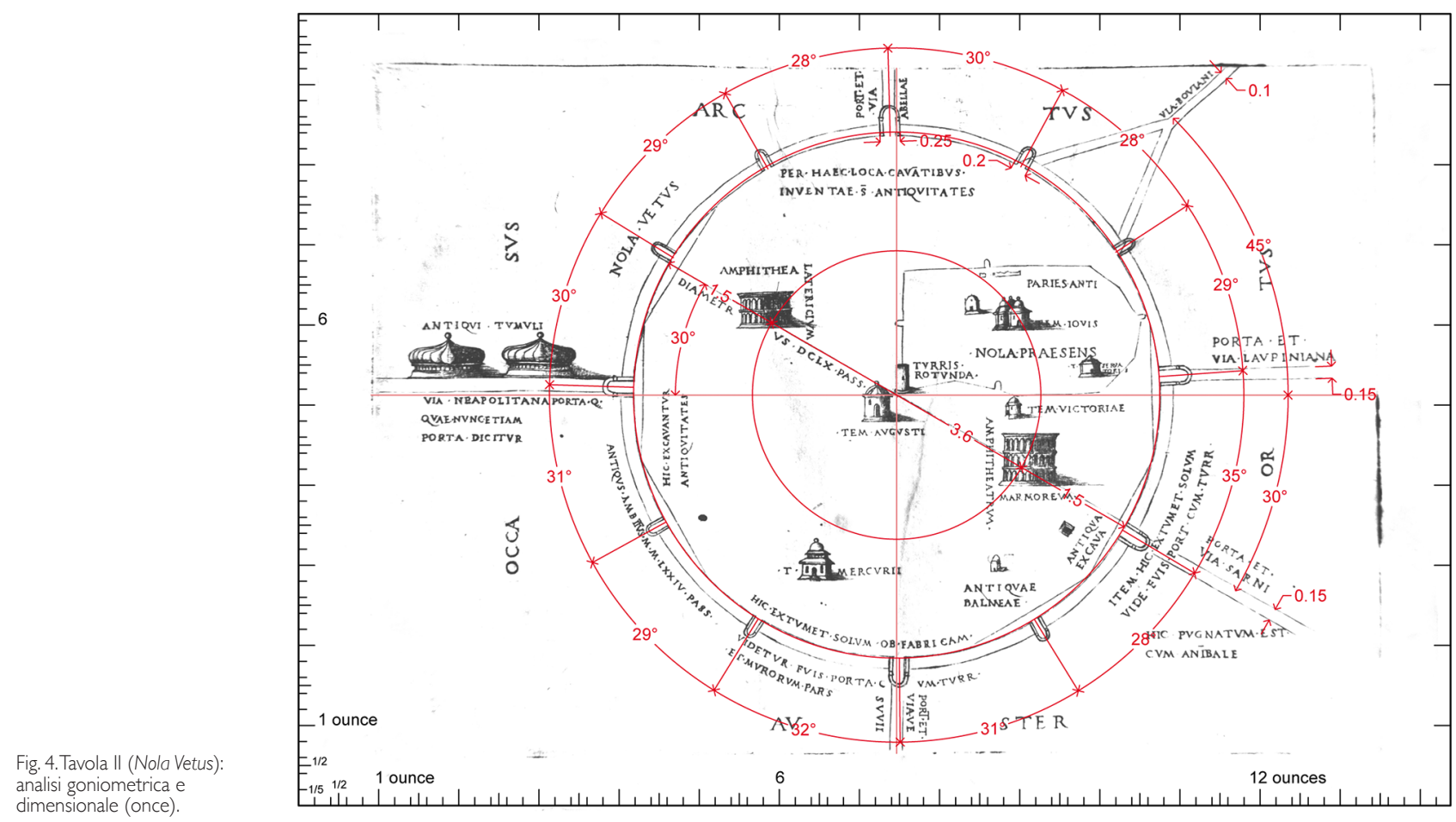
il disegno delle strade che si irradiano dalle porte potrebbe rafforzare questa gerarchia: le strade principali sono larghe 0,15 once, le altre 0 , I once.

II disegnatore inserisce nella Tavola II una sola informazione dimensionale ovvero il diametro dell'impianto circolare della città antica pari 660 passi. Questo segmento disegnato è 6,6 once, come si evince dalla figura 4. È evidente, pertanto, che il disegnatore applica una proporzione di 1:I00 tra once e passi. Questa proporzione trova riscontro anche nella distanza relativa tra i due Anfiteatri e nella equidistanza tra questi e la cinta muraria. Nel disegno, tracciata una circonferenza di diametro 3,6 once, questa intercetta le due icone degli anfiteatri.

I dati geometrici e dimensionali sin qui acquisiti aprono a valutazioni sulla pratica grafica del disegnatore e, a propria volta, sul progetto grafico della Tavola II.

Integrando quanto già acquisito dall'analisi grafica delle altre tre Tavole del Trattato con le valutazioni dimensionali precedenti, è possibile affermare che il disegnatore utilizzava l'oncia come unità di riferimento delle lunghezze con i suoi sottomultipli pari a 1/2, 1/4, 1/5 (ovvero I minuto di oncia). Meno probabile che il disegnatore si sia spinto fino a $1 / / 0$ e I/20 oncia: la prima potrebbe essere stata tracciata come media a vista del "minuto di oncia"; la seconda, invece, non avrebbe riscontri pratici al tempo ed è stata desunta in questa analisi grazie all'accuratezza combinata dell'ortorettifica dell'immagine e del disegno vettoriale. $\grave{E}$ immaginabile che il disegnatore avesse tra le mani un compasso e un righello scandito in once, quindi in metà oncia, ed ancora in quarti di oncia e in minuti di oncia. L'impronta metodologica sottesa alla figura 5 trae spunto da questa ipotesi. L'uso consapevole del compasso è invece desumibile dal regolare tracciamento delle circonferenze, due delle quali sono visibili ed altre sono sottese alla disposizione dei testi secondo allineamento circolare (fig. 6); ed ancora, è evidente dalla divisione in 12 parti uguali della circonferenza, utile alla distribuzione radiale delle porte urbiche e al disegno di un frammento del dodecagono. Visto che la disposizione radiale media delle porte oscilla di circa $7^{\circ}$, è ipotizzabile che il disegnatore avesse tracciato il dodecagono, di cui evidenzia due tratti di tre lati agli estremi del diametro, e nei punti medi dei lati di questo abbia posto le icone delle porte urbiche.

Nella figura 5, la Tavola II ha in sovrimpressione un grid modulare di once, metà oncia, e minuti di oncia, quale migliore risultato di una serie ordinata di ipotesi di disposizione in base alle dimensioni del foglio, oppure alla forma della cornice di impressione tipografica, oppure

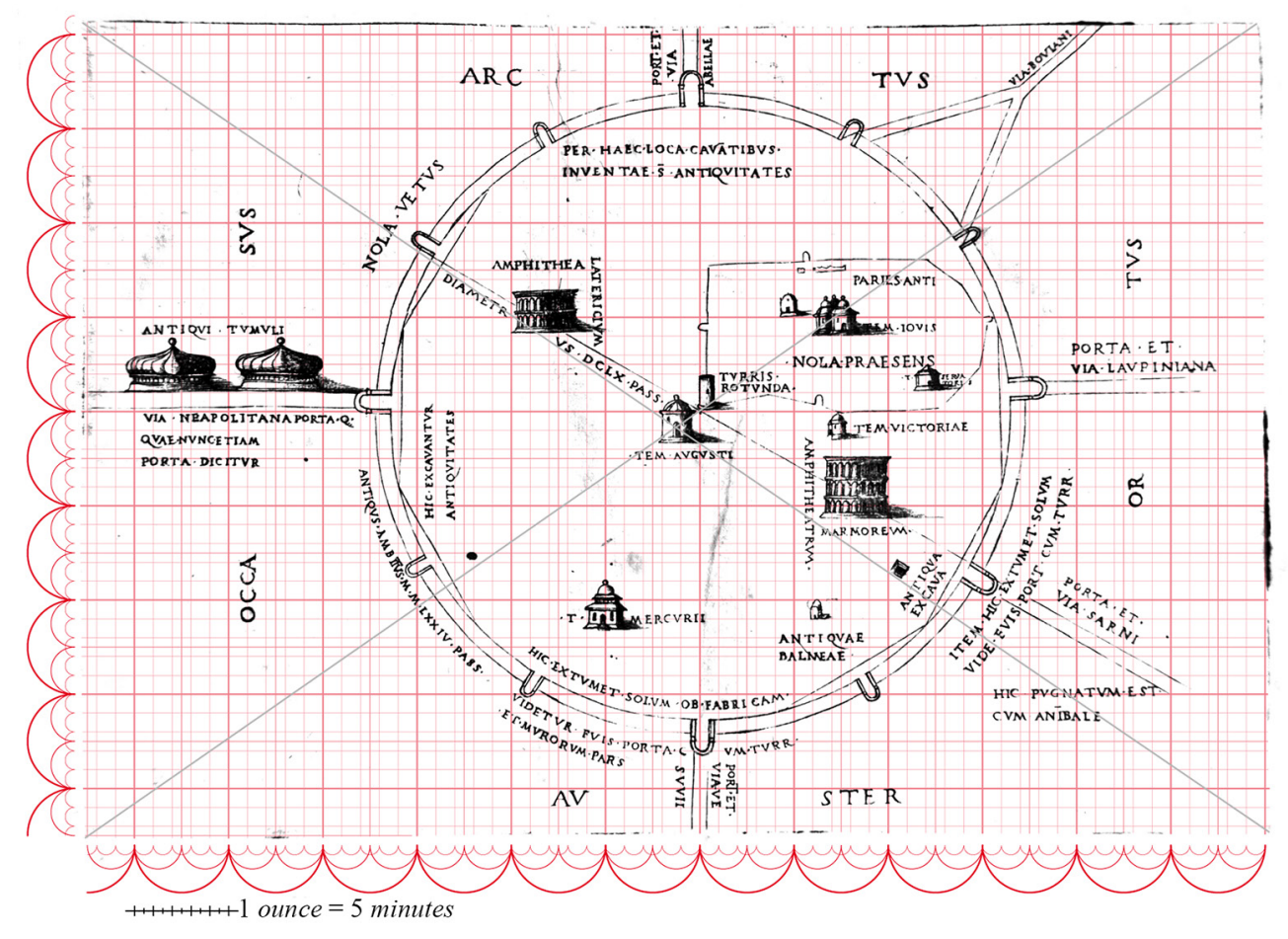


alla geometria delle circonferenze precedentemente esaminate, oppure ai lati disegnati del dodecagono, oppure alle giaciture dei testi nella tavola. Le direzioni principali del grid della figura 5 coincidono con la coppia di assi ortogonali già utilizzati nella figura 4 con il centro della circonferenza della cinta muraria, la cui origine appartiene ad una delle due diagonali della cornice di impressione tipografica. Questo è un ulteriore elemento grafico che avvalora l'individuazione del centro della circonferenza, descritto nella figura 4. Nell'intersezione delle due diagonali, il disegnatore colloca l'icona del Tem Augusti, probabilmente al fine di dare centralità alla figura dell'imperatore Gaio Giulio Cesare Ottaviano Augusto - primo imperatore romano - che morì a Nola il 19 agosto del 14 dopo Cristo, cinquecento anni prima dell'edizione del De Nola.

La lettura comparativa della Tavola II e del grid della figura 5 evidenzia numerose altre singolarità circa le icone utilizzate per le architetture civili e religiose della città antica. II lettore potrà notare che la disposizione, la forma e la proporzione delle icone non è casuale rispetto al grid. Così come, la disposizione e l'altezza dei testi lineari, non è casuale (fig. 6); quelli curvilinei seguono una diversa geometria descritta nella figura 6. II grid della figura 5 manca della suddivisione in metà del minuto di oncia perché essa avrebbe infittito molto il disegno rendendolo illeggibile. Se si osserva attentamente, è possibile notare che molti testi ed alcune icone sono riconducibili a questo sottomultiplo che - come precedentemente detto - non è riscontrabile nella letteratura in materia; viste le sue dimensioni minime $(\mathrm{mm}$ 2,2 ) è ipotizzabile che fosse una dimensione utilizzata per prassi artigianale e non codificata.

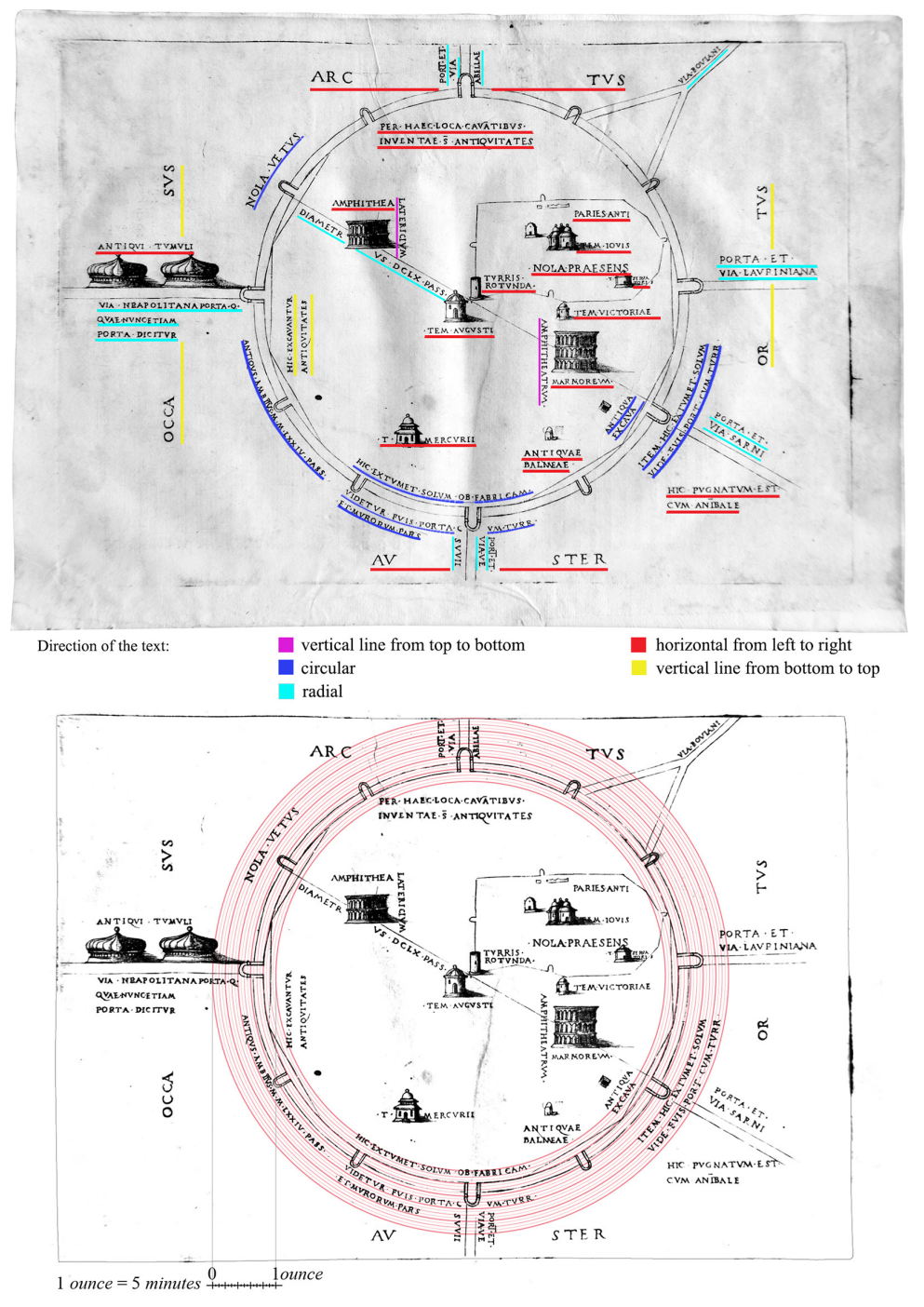




\section{Conclusioni}

In questa ricerca, la sovrapposizione del grid della figura 5 alla Tavola II è servita per avere un riferimento analitico che permettesse di valutare la composizione dell'immagine in un sol colpo d'occhio. II disegnatore della tavola molto probabilmente non elaborò un riferimento così accurato - che è utilizzato nella grafica digitale contemporanea - ma è evidente che egli elaborò un progetto grafico unitario della Tavola con chiari riferimenti geometrici e modulari.

La lettura integrata dei dati desunti dalle analisi finora condotte sulle Tavole del De Nola [I 3] sistematizzati nel progetto GIS hanno evidenziato alcune valutazioni critiche già discusse nel presente testo e nei contributi pubblicati in questo volume [14], ed altre che potranno essere ulteriormente ampliate nel campo archeologico e topografico. Nel primo si potrà far riferimento alla localizzazione cartografica di tutte le campagne di scavo archeologico condotte sul territorio così come dei dati descrittivi desumibili da documenti e dalla bibliografia di settore sul tema, nel secondo ai metodi, alle tecniche e quindi agli strumenti di rilevamento in uso al tempo. La sintesi di tutte le informazioni raccolte ed elaborate nell'ambito della più ampia ricerca condotta potrà essere di ulteriore supporto all'analisi delle Tavole del Leone che disvelano una personalità poliedrica di disegnatore, topografo e tipografo oltre che di erudito umanista [15].

\section{Note}

[I] Argenziano, Avella, Pisacane 2021, pp. 883-894; Avella, Pisacane, Argenziano 2020, pp. I598-I62I; Pisacane, Argenziano, Avella (in corso di stampa).

[2] II contributo è parte integrante della ricerca in corso sulle iconografie del Trattato De Nola condotta dall'autrice del presente saggio con Pasquale Argenziano e Nicola Pisacane. In particolare, la lettura iconografica è completata dai saggi Argenziano P., Il disegno della città nelle Tavole del De Nola. Metodi della rappresentazione e della tipografia e Pisacane N., II disegno della città nelle Tavole del De Nola. Analisi degli aspetti geografici e cartografici.

[3] L'analisi dei quattro disegni è condotta su uno degli esemplari della prima edizione a stampa conservati nella Biblioteca Nazionale di Napoli, la cui collocazione è SQ.LVI.D. I6. Successivamente alla prima edizione curata da Leone e verosimilmente da Mocetto, il De Nola vanta sei edizioni latine in volumi miscellanei o monografici e due traduzioni in italiano (1934; 1997).

[4] Ambrogio Leone (Nola I 458 ca - Venezia 1525) è una singolare figura della cultura italiana rinascimentale, di collegamento tra gli ambienti degli eruditi napoletani, quelli veneziani e quelli d'oltralpe che frequentavano le rispettive capitali (Spruit 2005).

[5] (Leone I5|4, bks. III, 7).

[6] I Gigli di Nola rientrano, unitamente alla Nostra Signora della Santa Lettera di Palmi, alla Discesa dei Candelieri di Sassari e alla Macchina di Santa Rosa di Viterbo, nella Rete delle grandi macchine a spalla italiane, iscritta dal 2013 nella Lista del Patrimonio Culturale Immateriale dell'UNESCO.

[7] Vagnetti 1973; Pagnano 2003; Zerlenga 2004.

[8] Per una descrizione dettagliata della Tavola II (Nola Vetus) si rimanda al saggio di P. Argenziano pubblicato nel presente volume di Atti.

[9] Le procedure di orto-rettifica delle immagini sono descritte in: Argenziano, Avella, Pisacane 202 I, p. 885.

[ I0] L'unità di misura dell'oncia quale sottomultiplo del palmo e del passo corrisponde a 21,972 mm. Tali unità sono state codificate nell'editto del 6 aprile I 480 dal re Federico I d'Aragona e il passo corrisponde a I,84569 metri (Afan de Rivera | 840). II passo aveva come immediato sottomultiplo il palmo (detto anche palmo napoletano); I palmo è I/7 di passo. II palmo aveva come suo sottomultiplo l'oncia; I oncia è |/I2 di palmo oppure |/84 di passo. L'oncia aveva due sottomultipli alternativi; il primo era il minuto (I minuto è I/5 di oncia), il secondo era il punto (I punto è I/I2 di oncia); metà oncia era uguale a 6 punti (Visconti, 1838).

[I I] Ruggero 1997, p. 261.

[12] Nella Tavola Nola Vetus l'inquadramento geografico della città antica è descritto attraverso gli orientamenti cardinali riportati nella mezzeria dei quattro lati della Tavola ed indicati con Arctus (Nord), con Auster (Sud), con Ortus (Est) e con Occasus (Ovest), facendo riferimento alle costellazioni in cui il Sole viene a trovarsi al sorgere o al tramonto (Ruggero 1997, p. I09).

[I3] Vedi nota I.

[I 4] Vedi nota 2 .

[15] Le immagini a corredo del testo, ad eccezione di quelle di repertorio, sono a cura di Alessandra Avella, Pasquale Argenziano, Nicola Pisacane. 


\section{Riferimenti bibliografici}

Afan de Rivera C. ( 1840$)$. Tavole di riduzione dei pesi e delle misure delle due Sicilie in quelli statuiti dalla legge de’ 6 aprile 1840 Napoli: Stamperia e cartiere del Fibreno.

Aguilar-Camacho J., Granado-Castro G., Barrera-Vera J. A. (2019). Urban mapping of Cadiz during the War of Spanish Succession: a paradigm of the cartography enterprise undertaken by the Military Engineer Corps. In Disegnarecon, vol. I2, n. 22, pp. I.I-I.I9.

Argenziano P., Avella A., Pisacane N. (2021). Geometry and Urban Shape of the City of Nola through the Drawings of the De Nola by A. Leone (I |4). In L.-Y. Cheng (a cura di). I th ICGG 2020. Proceedings of the $19^{\text {th }}$ International Conference on Geometry and Graphics, Advances in Intelligent Systems and Computing, vol. I296, pp. 883-894. Switzerland: Springer.

Avella A., Pisacane N., Argenziano P. (2020). The drawing of the Renaissance city from De Nola's tables to contemporary cartographical data. In A. Arena (a cura di). Connettere. Un disegno per annodare e tessere. Atti del $42^{\circ}$ Convegno Internazionale UID, pp. I598-1621. Milano: FrancoAngeli.

Cajthaml J. (20I I). Methods of georeferencing old maps on the example of Czech early maps. In A. Ruas (Ed.). Proceedings of the 25th International Cartographic Conference. Parigi, 3-8 luglio 201I. <https://icaci.org/files/documents/ICC_proceedings/ICC20 I I/Oral\%20Presentations\%20PDF/D I-Digital\%20technologies\%20and\%20cartographic\%20heritage/CO-3 | 4.pdf> (consultato il 28 aprile 2021 ).

Campone M.C. (2015). Figura praesentis urbis Nolae: geometric theorems and classical sources in Renaissance's urbanism and in De Nola by Ambrogio Leone. In C. Gambardella (a cura di). Heritage and Technology. Mind Knowledge Experience, Att del XIII Forum Internazionale di Studi "Le Vie dei Mercanti". Aversa-Capri, I I- I 3 June 20 I 5, pp. I 855- I 864. Napoli: La Scuola di Pitagora editrice.

Carillo S. (1996). Alcune osservazioni sulla pianta della città allegata al De Nola di Ambrogio Leone. In T. R. Toscano (a cura di). Nola e il suo territorio dalla fine del Medio Evo al XVII secolo. Momenti di storia culturale e artistica, pp. 25-44. Castellammare di Stabia: Ager Nolanus.

De Seta C., Buccaro A. (a cura di). (2006). Iconografia delle città in Campania. Napoli e i centri della provincia. Napoli: Electa Napoli.

Jenny B., Hurni L. (201 I). Studying cartographic heritage: Analysis and visualization of geometric distortions. In Computers \& Graphics, n. 35, pp. 402-411.

Leone A. ( I | 4). De Nola. Opusculum distinctum, plenum, clarum, doctum, pulchrum, verum, grave, varium, et utile. Venezia: Giovanni Rosso.

Leone A. (1934). Nola (la terra natia).Traduttore Paolino Barbati. Napoli:Tipografia Torella.

Leone A. (1997). Nola.Traduttore Andrea Ruggiero. Istituto Grafico Editoriale Italiano.

Manzi P. (1973). Alcuni documenti di cartografia nolana ovvero: Ambrogio Leone e Gerolamo Moceto. In L'Universo, vol. LIII, n. 4, pp. 8||$-8 \mid 8$.

Pagnano G. (2003). Presentazione. In G. Pagnano (a cura di). Ikhnos. Analisi grafica e storia della rappresentazione, vol. I, pp. 7- I 0 . Siracusa: Lombardi Editori.

Pisacane N., Argenziano P., Avella A. (in corso di stampa). The Ager Nolanus Table by Ambrogio Leone and Girolamo Mocetto as prototype of modern cartography.

Sampaolo V. (1996). Nola. In Enciclopedia dell'Arte Antica Treccani, vol. V, p. 537. <https://www.treccani.it/enciclopedia/nola res-488d774b-66c0- I le I-b49|-d5ce3506d72e_\%28Enciclopedia-dell\%27-Arte-Antica\%29/> (consultato il 280aprile 202I).

Sardi P. ( 6 |8). Corona imperiale dell'architettura militare. Venezia: Barezzo Barezzi.

Spruit L. (2005). Leone, Ambrogio. In Dizionario Biografico degli Italiani. Treccani, vol. 64, <https://www.treccani.it/enciclopedia/ ambrogio-leone_(Dizionario-Biografico)> (consultato il 28 aprile 202I).

Vagnetti L. (1973). L'architetto nella storia di Occidente. Firenze:Teorema.

Visconti F. ( 1838). Del sistema metrico della città di Napoli e della uniformità de' pesi e delle misure che meglio si conviene a' reali domini di qua dal faro. Napoli: Stamperia Reale.

Vladimiro V. (1998). Piante e vedute di Napoli dal 1486 al 1599. L'origine dell'iconografia urbana europea. Napoli: Electa.

Zerlenga O. (2004). II disegno della città. Napoli rappresentata in Pianta e Veduta. In G. Pagnano (a cura di). Ikhnos. Analisi grafica e storia della rappresentazione, vol. II, pp. I I-34. Siracusa: Lombardi Editori.

Autore

Alessandra Avella, Università della Campania “Luigi Vanvitelli”, alessandra.avella@unicampania.it

Per citare questo capitolo: Avella Alessandra (2021). II disegno della città nelle tavole del De Nola. Analisi geometrico-dimensionale delle iconografie/City drawing in De Nola's tables. Geometric-dimensional analysis of the iconographies. In Arena A., Arena M., Mediati D., Raffa P. (a cura di). Connettere. Un disegno per annodare e tessere. Linguaggi Distanze Tecnologie. Atti del $42^{\circ}$ Convegno Internazionale dei Docenti delle Discipline della Rappresentazione/Connecting. Drawing for weaving relationship. Languages Distances Technologies. Proceedings of the $42^{\text {th }}$ International Conference of Representation Disciplines Teachers. Milano: FrancoAngeli, pp. |4|-158. 


\title{
City Drawing in De Nola's Tables. Geometric-Dimensional Analysis of the lconographies
}

\author{
Alessandra Avella
}

Abstract

This paper introduces the analysis of the ancient city of Nola through the comparative study of two Tables among the four attached to De Nola Treatise (15/4) by Ambrogio Leone, also in comparison with the contemporary city. These drawings are an important graphic-documentary testimony of the finds of the ancient city in the Renaissance period as well as the theoretical-geometric knowledge of the author discussed in this essay. Starting from the graphic analysis of Table II entitled Nola Vetus, this research studies its geometric-dimensional aspects, based on the Science of Drawing, not only for a critical reinterpretation of Tables attached to Treatise but also to connect the ancient city to the traces still today present in the contemporary territory.

This essay consolidates the multifaceted character of the author as a draftsman, topographer and typographer as well as a humanist scholar, together with the essays by Argenziano and Pisacane in this Proceedings book and in continuity with the research already presented at the UID 2020 Conference.

Keywords

documentation, geometry, reference unit, treatise, UNESCO.

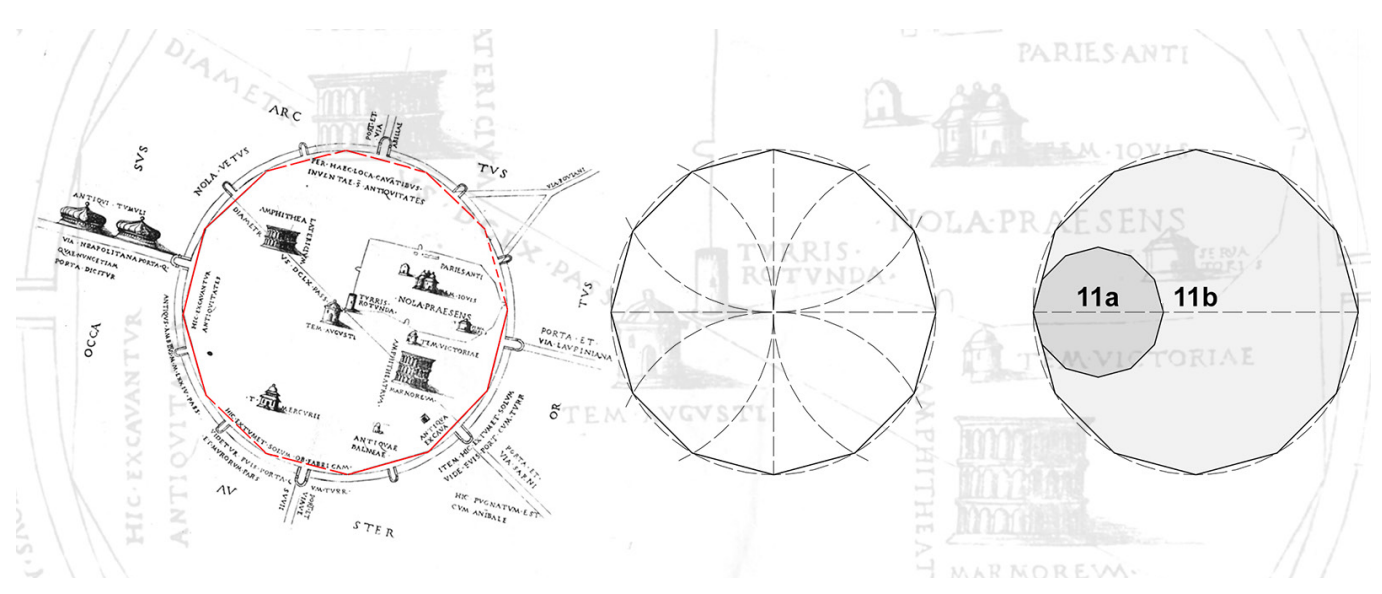




\section{Introduction}

This paper continues [I] and integrates [2] the study of the four drawings attached to the first printed edition [3] of De Nola Treatise by Ambrogio Leone [4] through the geometric and graphic analysis of Table II entitled Nola Vetus. These four drawings are an important graphic-documentary testimony of the Renaissance Nola described by Leone in the three books in which he organizes his work. In the first book the author describes the Nola territory according to a chronological reading and with a wide dissertation on the classical city. In this book there are Ager Nolanus Table (Table I) and Nola Vetus Table (Table II); in the second book, he describes the contemporary city and its structure with in-depth analysis about the defensive elements, the aristocratic, religious and civil buildings. In this book there are Figura praesentis urbis Nolae Table (Table III) and Nola Presens Table (Table IV). Finally, he describes the uses and traditions of his fellow citizens, including the tradition of Festa dei Gigli [5] celebration, from whose study the analyses ongoing on the De Nola's illustrative material have drawn inspiration. These analyses are part of a wider research developed within the Research Project funded by Regione Campania aimed at the study for the safeguard and enhancement of the cultural elements of the Gigli di Nola obelisks registered on the UNESCO Intangible Heritage List [6].

According to the methodological approach of the discipline of Drawing [7] already adopted for the analysis of Tables I, III and IV, the analyses of Table II are of the geometricdimensional type and concern the methods of representation, typographical characteristics and geographical ones compared to contemporary cartography. In particular, this study describes and illustrates the geometric-dimensional analyses performed on the Nola Vetus Table in comparison with the Figura praesentis urbis Nolae Table, as discussed in the following paragraph.

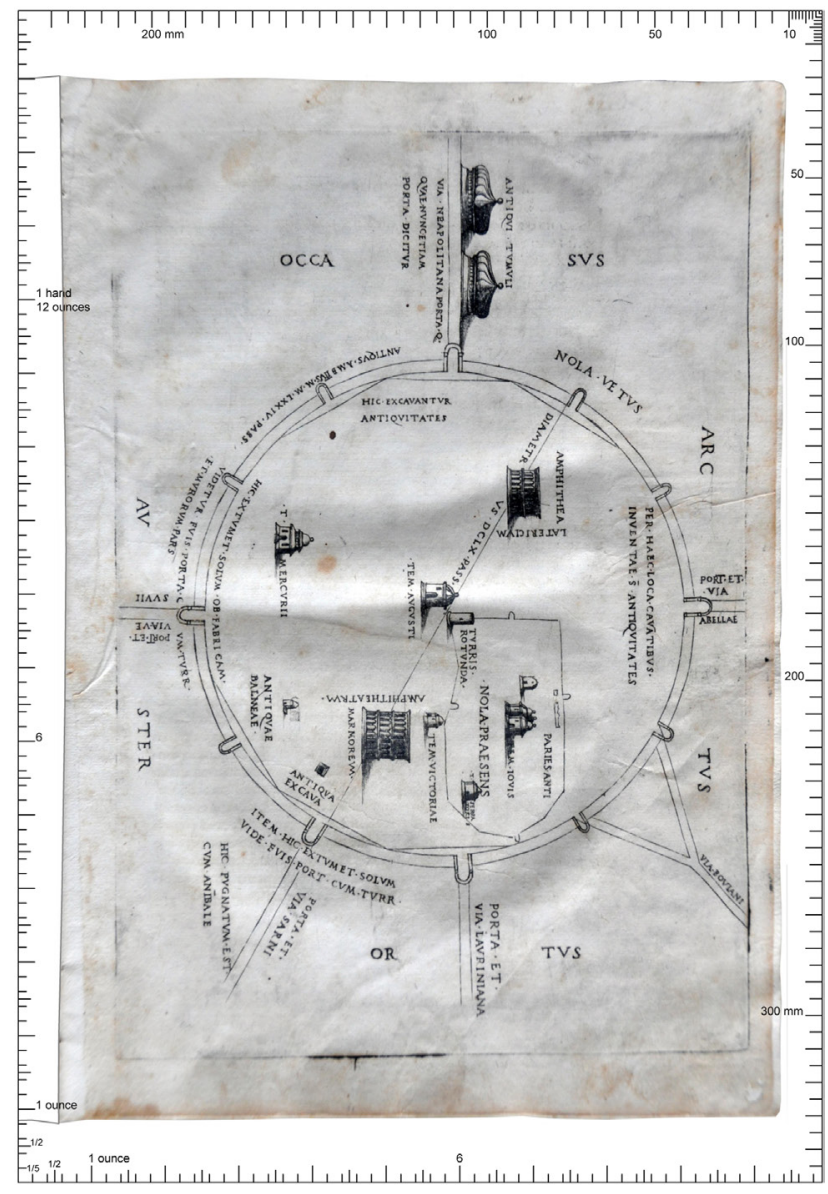




\section{Geometric and dimensional layout of the Nola Vetus and the Figura praesentis urbis Nolae Tables}

This study of the Nola Vetus Table (Table II) [8] -which illustrates the ancient city of Nolaand of its description in Chapters VII and VIII of the first book, is carried out starting from the results already obtained following the geometric and algebraic analysis of Figura praesentis urbis Nolae Table (Table III), the only one of the four Tables in which the author makes an accurate description of the drawing also with precise references both to the perimeter and to the extension of the city of Nola, both in Roman times and in the Renaissance period.

In figures I and 2 the images of Nola Vetus Table and Figura praesentis urbis Nolae Table are ortho-rectified according to the procedure used for the other two Tables [9] and are oriented according to the arrangement in the pages of the Treatise (the binding margin on the left is highlighted with a marked segment). The internal surface at the edge of the sheets is flat and the image has been re-projected according to an orthogonal direction; nevertheless, the deformations in some areas of the sheet may not have been corrected. The frame of figures $I$ and 2 is marked in centimeters and millimeters [I0], as well as in spans (palmi) and ounces (once) which are the proportional units of measurement in use at the Leone's period in the Kingdom of Naples for lengths of small objects.

The metric and geometric evaluations proposed by Leone to comment on Table III are necessary for the comparison that he conducts between the circular shape of the ancient city and the polygonal shape of the Renaissance city. The author himself declares this in the descriptive text, explaining that the aim of this operation is to determine "the correct

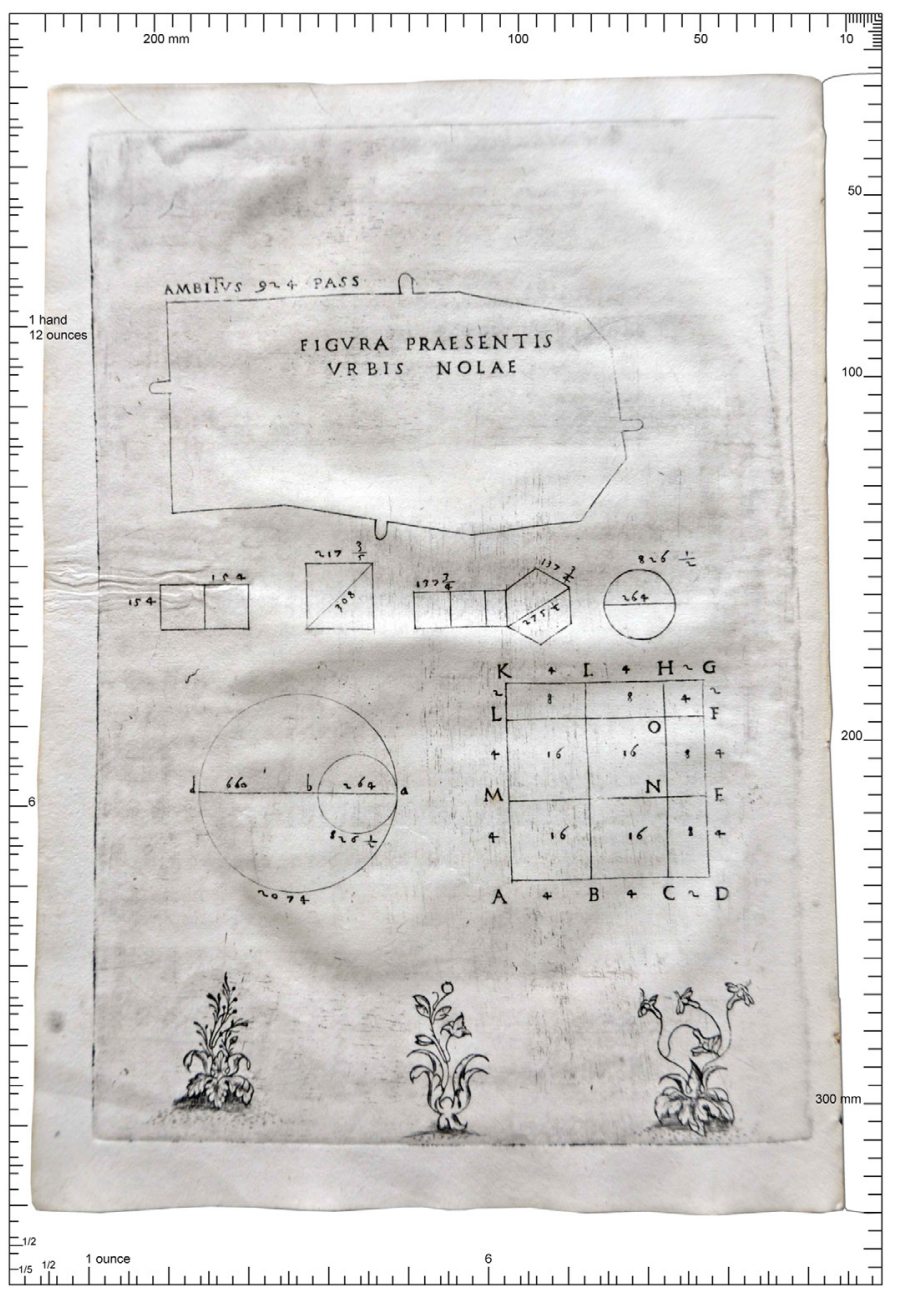


diameter comparable with the diameter of the ancient city" [I I ]. Leone traces the irregular shape of the Renaissance city to that of a circumference through geometric transformations of the starting polygon on the basis of critical evaluations relating to the equivalence between figures. Then from the irregular starting polygon of the Renaissance city, which he simplifies through two squares side by side with an equivalent total surface area, he arrives at the circumference of the ancient city through the geometric figures of the square, the hexagon and the twelve-sided polygon. The dodecagon scaled in the dimensions of the Roman city allows him to place the twelve gates of the city at the top.

All the geometric drawings of Table III are furnished with texts that in some cases indicate the perimeters of the figures, in others the dimensions of the individual segments making up the polygons and the dimensions of the circumferences. The measures are expressed in steps (passus) and the submultiples of the unit are fractional and not decimal, as in use at the time. The dimensional data obtained through the graphic analysis, the metric estimates and the digital re-drawing of the geometric figures of Table III made it possible to calculate the scale of representation of the Table and of all the drawings represented in it. Figura paesentis urbis Nolae Table is drawn in ounces, each ounce is equivalent to 60 'true' steps; regular geometric figures are on average five times smaller than it. Considering the spans as a unit of measurement, the scale of representation of each geometric figure is approximately 1:2000. This heterogeneity made it necessary to scale the Tables to only one of them to calculate the error between the dimensions written by Leone and the drawings. As a result of this operation, it was possible to verify that the calculated error can be considered negligible.

Starting from these dimensional data in Table III, and in particular those relating to the dodecagon inscribed in the circumference with a diameter of 660 steps, a comparison was made with the dimensional data indicated in Table II. Specifically, figure 3 explains not only the geometric analysis of the drawings in Figura praesentis urbis Nolae Table, but also the description that the author proposes in the descriptive Chapter of the same Table, which also contains considerations relating to the geometric figures of the hexagon and the dodecagon. Precisely the considerations referred to the dodecagon allowed the comparison
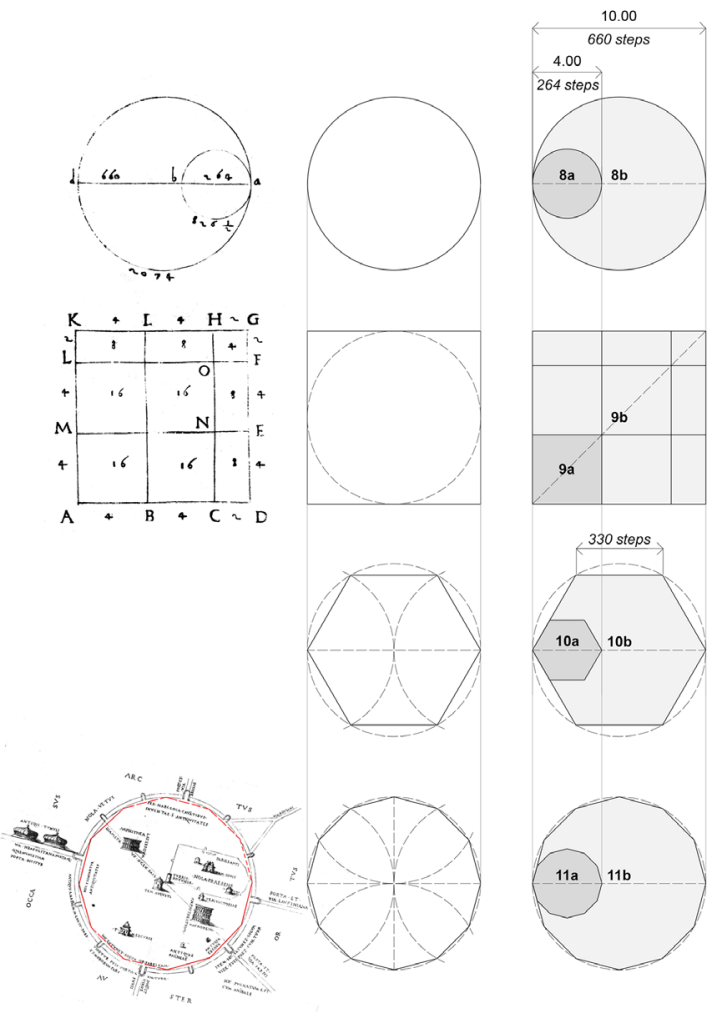
with Nola Vetus Table. Leone traces six of the twelve sides of the dodecagon within the circular perimeter of the walls of the ancient city, placing the urban gates at the midpoints of the sides.

Table II introduces graphic elements useful for the proportioning of the image and its parts, as already verified in the other Tables of the Treatise. The ratio between the sides of the rectangular letterpress frame (in the Table is not visible a drawn frame) is 12,5:8,5 ounces. The characteristic geometry of this Table is evidently the circumference, the center of which has been identified on the segment indicated as diametrus at the intersection with a straight line passing through the left vertical margin of the icon indicated as Turris Rutunda. Among the possible circles traced in CAD software -by means of Pascal's Theorem- the one that traces the greater extension of the smaller circumference drawn in the Table has been chosen. It should be noted that the latter differs from the regular one in the upper part of the Table (Arctus) [12]; in this part, the sheet is deformed perhaps due to the effect of humidity and also due to wear caused by the flipping of the pages; the Arctus margin of the Table is in fact that of the book leaf as it is evident in Figure I in which the sheet is arranged according to the book leaf.

It should be noted that a small spot that could be the residual trace of the ink concentration in the point (or small hole) where the draftsman placed the compass needle on the printing plate is noticeable at a negligible distance from the centre of the regular circumference plotted in figure 4, and therefore from the diametrus segment. This graphic trace could be another clue to confirm the validity of the vector regular circumference, used as a geometric reference for all the analyses performed in this paper and in the essays by Argenziano and Pisacane published in this Proceedings book, to which reference is made for a complete reading of the research performed on this topic.

In figure 4, a system of orthogonal axes originates in the centre of the circumference with the vertical axis tangent to the left margin of the Turris Rutunda icon; the vertical axis is therefore in the Arctus-Auster direction. Compared to the system of orthogonal axes, it can be seen that the segment indicated as diametrus is inclined by $30^{\circ}$; and again, it is noted that the average vertical axes of the twelve urban gates are arranged along the circumference with angular variations that oscillate between $28^{\circ}$ and $35^{\circ}$. Furthermore, the icons of the urban gates are of two dimensions: those open towards the main cardinal directions and
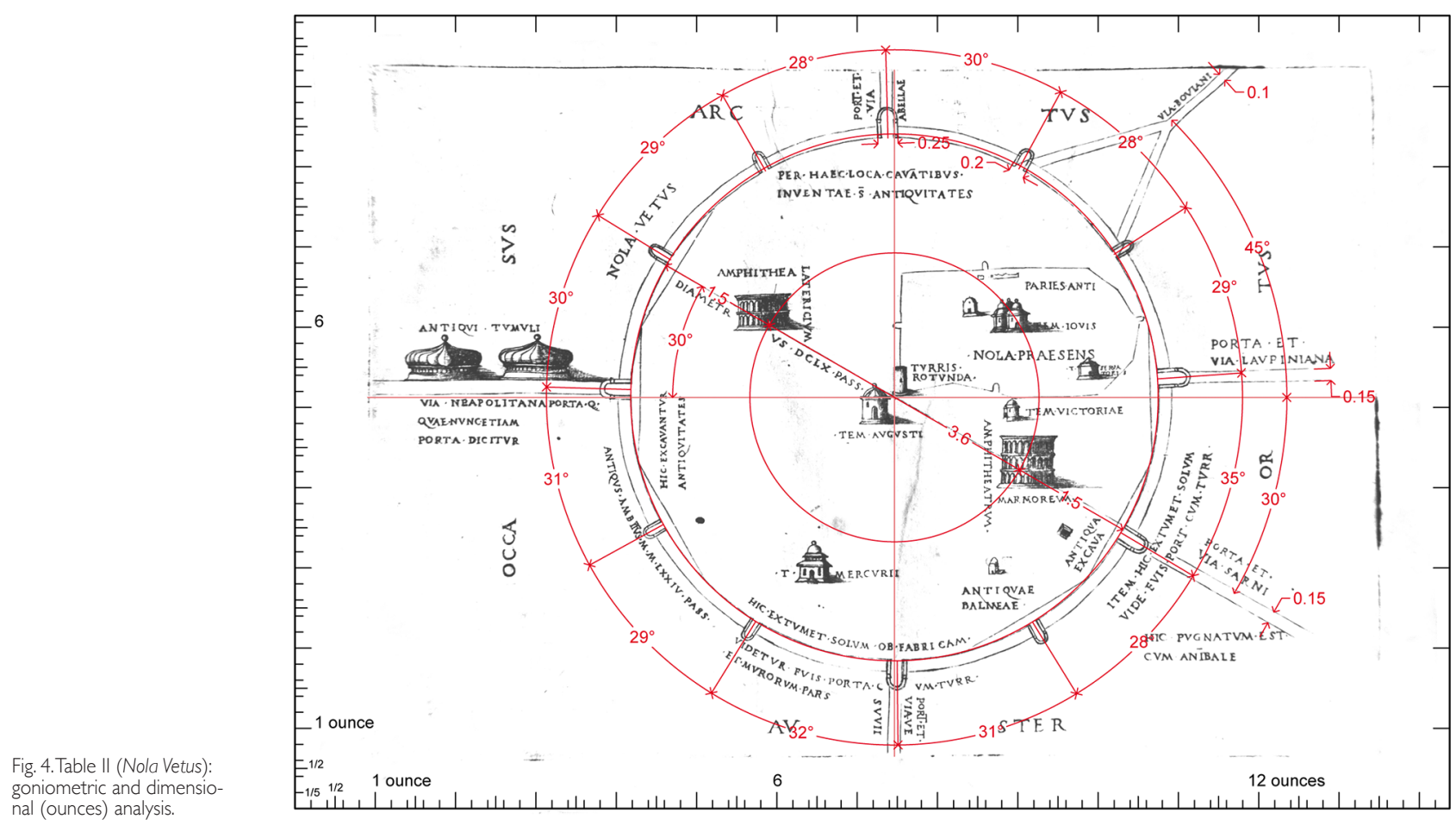
the one at the lower end of the drawn diameter are 0,25 ounces wide and 0,4 ounces high; while all the others are approximately 0,2:0,3 ounces. This could allude to a hierarchy in the function of these gates. The drawing of the streets radiating from the urban gates could also reinforce this hierarchy: the main streets are 0,15 ounces wide, the other 0,1 ounces wide.

The diameter of the circular layout of the ancient city equal to 660 steps is the only dimensional information that the draftsman enters in Table II. This drawn segment is 6,6 ounces, as shown in figure 4. It is evident, therefore, that the draftsman applies a ratio of $1: 100$ between ounces and steps. This proportion is also reflected in the relative distance between the two Amphitheatres and in the equidistance between them and the urban walls. In the drawing, if a circumference with a diameter of 3,6 ounces is drawn, it intercepts the two icons of the Amphitheatres.

The geometric and dimensional data acquired open up assessments of the graphic capabilities of the draftsman and of the graphic design of Table II.

Thanks to the comparison among the published graphic analysis of the other three Tables of the Treatise and the dimensional evaluations described above, it can be said that the draftsman used the ounce as lengths' reference unit and its submultiples equal to I/2, I/4 and I/5 as I minute of ounce. It is less likely that the draftsman used distances equal to $1 / 10$ and I/20 ounces: the first one may have been plotted as a visual average of I minute of ounce; the second one would have no practical evidence at that time, and it was calculated in this analysis thanks to the combined accuracy of the ortho-projected image and CAD drawing. It is more reliable, in fact, the hypothesis that the draftsman had in his hands a compass, and a ruler marked in ounces, then in 1/2 ounce, and again in 1/4 ounce and in minutes of ounce. The methodological imprint of figure 5 is based on this hypothesis. The conscious use of the compass by the draftsman can be deduced from the regular tracking of the circumferences, two of which are visible and others are underlying the texts according to circular alignment (fig. 6); and again, the use of the compass is evident from the division into 12 equal parts of the circumference, useful for the radial distribution of urban gates, and the drawing of a part of the dodecagon. Since the average radial position of the urban gates shifts by about $7^{\circ}$, it is thinkable that the draftsman had drawn the dodecagon (this figure is fragmentary, two parts made of three sides each, and placed at the ends of the diameter are visible), and in the midpoints of its sides placed the icons of the urban gates. In figure 5, Table II has superimposed a modular grid proportional to ounces, to 1/2 ounce, and minutes of ounces. The

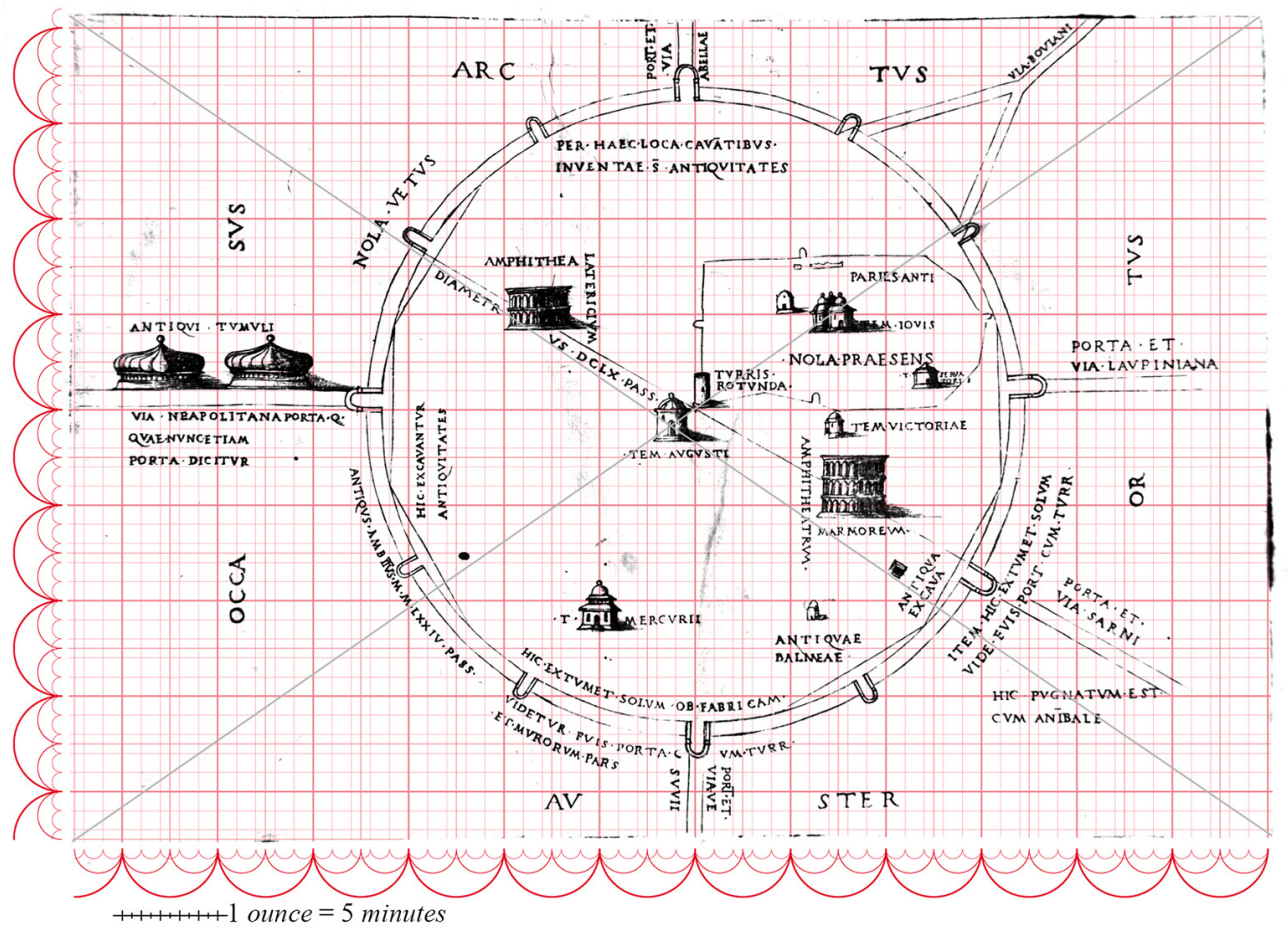


position of this grid is the best result of an ordered set of arrangement hypotheses, tried according to the size of the sheet, or to the shape of the typographic impression frame, or to the geometry of the circumferences previously examined, or to the drawn sides of the dodecagon, or then, to the texts frames in the Table. The main directions of the grid in Figure 5 coincide with the pair of orthogonal axes already used in figure 4, placed in the centre of the urban wall circumference, the origin of which belongs to one of the two diagonals of the typographic impression frame. This is a further graphic element that supports the identification of the centre of the circumference, described in figure 4. At the intersection of the two diagonals, the draftsman placed the icon of the Tem Augusti, probably in order to focus the emperor Gaius Julius Caesar Octavian Augustus -the first Roman emperor-who died in Nola on August 19th, 14 after Christ, five hundred years before the edition of De Nola. The comparative reading between Table II and the grid of figure 5 highlights numerous other singularities about the icons used for the civil and religious buildings of the ancient city. The reader will notice that the arrangement, the shape and the proportion of the icons is not random compared to the grid. Just as, the arrangement and height of linear texts is not random (fig. 6); curved ones follow a different geometry.

The grid of figure 5 lacks the subdivision in the middle of the minute of ounce, because it would have greatly intensified the drawing, making it unreadable. If the reader observes carefully, it can be noted that many texts and some icons can be traced back to this submultiple although it is not known in the according literature, as already mentioned. Since the middle of the minute of ounce is about $2.2 \mathrm{~mm}$, it is conceivable that it was a size used for craft practice and not coded.

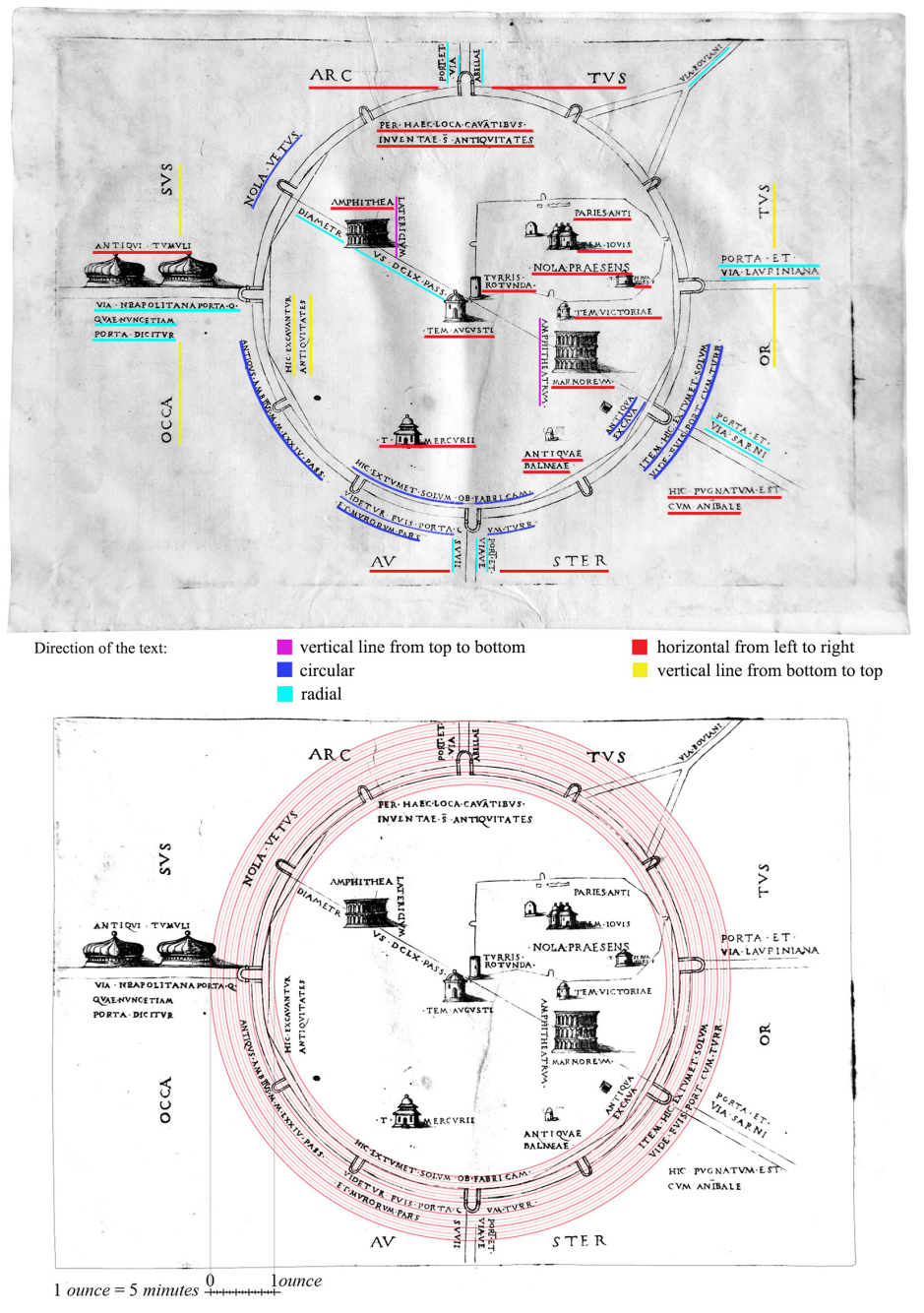




\section{Conclusions}

In this research, the grid of figure 5 overlay at Table II served to have an analytical reference that would allow to evaluate the composition of the image at a glance. The draftsman of the Table most likely did not elaborate such an accurate reference -which is used in contemporary digital graphics- but it is evident that he elaborated a unitary graphic design of the Table with clear geometric and modular references.

The integrated reading of the data obtained from the analyses carried out just published on the De Nola's Tables [13] systematized in the GIS project have highlighted some critical evaluations in this text and in the papers published in this Proceedings book [14], and others that could be further expanded in the archaeological and topographic field. In the first it will be possible to refer to the cartographic localization of all archaeological excavation campaigns conducted in the territory as well as descriptive data inferred from documents and bibliography on the subject, in the second to the methods, techniques and therefore to the detection tools in use at the time. This information, validated and discussed, may be a further support for the analysis of Leone's Tables that reveal a complex personality of draftsman, topographer and typographer beyond those of humanist scholar [15].

\section{Notes}

[I] See: Argenziano, Avella, Pisacane 2021, pp. 883-894; Avella, Pisacane, Argenziano 2020, pp. I598-I62I; Pisacane, Argenziano, Avella (in press).

[2] This paper is part of the ongoing research on the iconography of the De Nola Treatise carried out by the author of this essay with Pasquale Argenziano and Nicola Pisacane. In particular, the iconographic analysis is completed by the essays Argenziano P., City drawing in De Nola's Tables. The representation methods and typographic analysis and Pisacane N., City drawing in De Nola's Tables. Geographical and cartographical analysis features, published in this Proceedings book.

[3] The analysis of the four drawings is conducted on a copy of the first printed edition stored in the National Library in Naples; its shelfmark is SQ.LVI.D. I 6. After the first edition (1514) edited by Leone and probably by Mocetto, De Nola had six Latin editions in miscellaneous or monographic books, and two Italian translations (1934, 1997).

[4] Ambrogio Leone (Nola I 458 ca - Venice I525) is a singular person of Italian Renaissance culture, connecting the environments of the Neapolitan scholars, the Venetian ones and those from beyond the Alps who frequented their respective capitals [Spruit 2005].

[5] Leone I5|4, bks. III, 7 .

[6] Gigli di Nola obelisks are included, together with the obelisks of Nostra Signora della Santa Lettera of Palmi, Discesa dei Candelieri of Sassari and Macchina di Santa Rosa of Viterbo, in the "Network of large Italian shoulder machines", inscribed since 2013 in the UNESCO Intangible Heritage List.

[7] Vagnetti 1973; Pagnano 2003; Zerlenga 2004.

[8] For a detailed description of Table II (Nola Vetus) see the essay of P. Argenziano in this Proceedings Book.

[9] The image ortho-rectification procedures are described in Argenziano, Avella, Pisacane 2021, p. 885.

[10] The unit of measurement of the ounce, as a submultiple of the span and the step, corresponds to 21,972 millimeters. These units were codified in the Edict of 6 April I 480 by King Federico I d'Aragona and the step corresponds to I,84569 meters (Afan de Rivera 1840). The step had as immediate submultiple the span (also called palmo napoletano): I span is |/7 step. The span had the ounce as its submultiple; I ounce is I/I2 of I span or I/84 of I step. The ounce had two alternative submultiples: first was the minute (I minute is I/5 of I ounce), second was the point (I point is $|/| 2$ of I ounce); half of I ounce was equal to 6 points [Visconti, 1838].

[1 I] Ruggero 1997, p. 261.

[12] In Nola Vetus Table, the geographic framework of the ancient city is described through the cardinal orientations shown in the middle of the four sides of the Table and indicated with Arctus (North), Auster (South), Ortus (East) and Occasus (West), according to the constellations in which the Sun rises or sunsets (Ruggero 1997, p. 109).

[13] See endnote I.

[14] See endnote 2 .

[15] Figures, except for archive images, are edited by Alessandra Avella, Pasquale Argenziano, Nicola Pisacane. 


\section{References}

Afan de Rivera C. ( 840$)$. Tavole di riduzione dei pesi e delle misure delle due Sicilie in quelli statuiti dalla legge de’ 6 aprile 1840. Napoli: Stamperia e cartiere del Fibreno.

Aguilar-Camacho J., Granado-Castro G., Barrera-Vera J. A. (2019). Urban mapping of Cadiz during the War of Spanish Succession: a paradigm of the cartography enterprise undertaken by the Military Engineer Corps. In Disegnarecon, vol. I2, n. 22, pp. I.I-I.I9.

Argenziano P., Avella A., Pisacane N. (2021). Geometry and Urban Shape of the City of Nola through the Drawings of the De Nola by A. Leone (15|4). In L.-Y. Cheng (a cura di). I 9th ICGG 2020. Proceedings of the $19^{\text {th }}$ International Conference on Geometry and Graphics, Advances in Intelligent Systems and Computing, vol. I296, pp. 883-894. Switzerland: Springer.

Avella A., Pisacane N., Argenziano P. (2020). The drawing of the Renaissance city from De Nola's tables to contemporary cartographical data. In A. Arena (a cura di). Connettere. Un disegno per annodare e tessere. Atti del $42^{\circ}$ Convegno Internazionale UID, pp. I598-1621. Milano: FrancoAngeli.

Cajthaml J. (20I I). Methods of georeferencing old maps on the example of Czech early maps. In A. Ruas (Ed.). Proceedings of the 25th International Cartographic Conference. Parigi, 3-8 luglio 201I. <https://icaci.org/files/documents/ICC_proceedings/ICC20 | I/Oral\%20Presentations\%20PDF/D I-Digital\%20technologies\%20and\%20cartographic\%20heritage/CO-3 | 4.pdf> (accessed 2021, April 28)

Campone M.C. (2015). Figura praesentis urbis Nolae: geometric theorems and classical sources in Renaissance's urbanism and in De Nola by Ambrogio Leone. In C. Gambardella (a cura di). Heritage and Technology. Mind Knowledge Experience, Att del XIII Forum Internazionale di Studi "Le Vie dei Mercanti". Aversa-Capri, I I- I 3 June 20 I 5, pp. I 855- I 864. Napoli: La Scuola di Pitagora editrice.

Carillo S. (1996). Alcune osservazioni sulla pianta della città allegata al De Nola di Ambrogio Leone. In T. R. Toscano (a cura di). Nola e il suo territorio dalla fine del Medio Evo al XVII secolo. Momenti di storia culturale e artistica, pp. 25-44. Castellammare di Stabia: Ager Nolanus.

De Seta C., Buccaro A. (a cura di). (2006). Iconografia delle città in Campania. Napoli e i centri della provincia. Napoli: Electa Napoli.

Jenny B., Hurni L. (201 I). Studying cartographic heritage: Analysis and visualization of geometric distortions. In Computers \& Graphics, n. 35, pp. 402-411.

Leone A. ( I | 4). De Nola. Opusculum distinctum, plenum, clarum, doctum, pulchrum, verum, grave, varium, et utile. Venezia: Giovanni Rosso.

Leone A. (1934). Nola (la terra natia).Traduttore Paolino Barbati. Napoli:Tipografia Torella.

Leone A. (1997). Nola.Traduttore Andrea Ruggiero. Istituto Grafico Editoriale Italiano.

Manzi P. (1973). Alcuni documenti di cartografia nolana ovvero: Ambrogio Leone e Gerolamo Moceto. In L'Universo, vol. LIII, n. 4, pp. 8||$-8 \mid 8$.

Pagnano G. (2003). Presentazione. In G. Pagnano (a cura di). Ikhnos. Analisi grafica e storia della rappresentazione, vol. I, pp. 7- I 0 . Siracusa: Lombardi Editori.

Pisacane N., Argenziano P., Avella A. (in corso di stampa). The Ager Nolanus Table by Ambrogio Leone and Girolamo Mocetto as prototype of modern cartography.

Sampaolo V. (1996). Nola. In Enciclopedia dell'Arte Antica Treccani, vol. V, p. 537. <https://www.treccani.it/enciclopedia/nola_ res-488d774b-66c0-I le l-b49|-d5ce3506d72e_\%28Enciclopedia-dell\%27-Arte-Antica\%29/> (accessed 202I, April 28).

Sardi P. ( 6 |8). Corona imperiale dell'architettura militare. Venezia: Barezzo Barezzi.

Spruit L. (2005). Leone, Ambrogio. In Dizionario Biografico degli Italiani. Treccani, vol. 64, <https://www.treccani.it/enciclopedia/ ambrogio-leone_(Dizionario-Biografico)> (accessed 2021,April 28)

Vagnetti L. (1973). L'architetto nella storia di Occidente. Firenze:Teorema.

Visconti F. ( 1838). Del sistema metrico della città di Napoli e della uniformità de' pesi e delle misure che meglio si conviene a' reali domini di qua dal faro. Napoli: Stamperia Reale.

Vladimiro V. (1998). Piante e vedute di Napoli dal 1486 al 1599. L'origine dell'iconografia urbana europea. Napoli: Electa.

Zerlenga O. (2004). II disegno della città. Napoli rappresentata in Pianta e Veduta. In G. Pagnano (a cura di). Ikhnos. Analisi grafica e storia della rappresentazione, vol. II, pp. I I-34. Siracusa: Lombardi Editori.

\section{Author}

Alessandra Avella, Università della Campania “Luigi Vanvitelli”, alessandra.avella@unicampania.it

To cite this chapter. Avella Alessandra (2021). II disegno della città nelle tavole del De Nola. Analisi geometrico-dimensionale delle iconografie/ City drawing in De Nola's tables. Geometric-dimensional analysis of the iconographies. In Arena A., Arena M., Mediati D., Raffa P. (a cura di). Connettere. Un disegno per annodare e tessere. Linguaggi Distanze Tecnologie. Atti del $42^{\circ}$ Convegno Internazionale dei Docenti delle Discipline della Rappresentazione/Connecting. Drawing for weaving relationship. Languages Distances Technologies. Proceedings of the $42^{\text {th }}$ International Conference of Representation Disciplines Teachers. Milano: FrancoAngeli, pp. |4|-158. 